\title{
Physicochemical Properties of Kefir Manufactured by a Two-Step Fermentation
}

\author{
Sung-Ho Yoo, Ki-Seung Seong ${ }^{1}$, and Sung-Sik Yoon* \\ Division of Biological Science and Technology, Yonsei University, Wonju 220-710, Korea \\ ${ }^{1}$ Korea Food Research Institute, Seongnam 463-746, Korea
}

\begin{abstract}
The objective of this study was to assess the physicochemical and sensory changes of a kefir manufactured by a two-step fermentation (MTY, $1^{\text {st }}$ step: $37^{\circ} \mathrm{C}$ for $9 \mathrm{~h} ; 2^{\text {nd }}$ step: $24^{\circ} \mathrm{C}$ for $15 \mathrm{~h}$ ) and compare it with kefirs produced by two conventional methods (GTY, fermentation at $37^{\circ} \mathrm{C}$ for $24 \mathrm{~h}$; KEY, $22^{\circ} \mathrm{C}$ for $24 \mathrm{~h}$ ). Rapid changes in $\mathrm{pH}$ and titratable acidity (TA) were observed in samples from all three manufacturing methods during fermentation process and storage period. Lactic acid bacteria (LAB) counts of MTY increased gradually up to $12 \mathrm{~h}$ of fermentation, reaching $9.28 \mathrm{Log}$ CFU/mL, with maximum value observed in this experiment of $9.48 \mathrm{Log} \mathrm{CFU} / \mathrm{mL}$. The LAB counts of all samples decreased significantly during storage. The highest viscosity was observed for MTY (1750-1771 cPs), compared with the lowest viscosity observed for KEY (1250-1277 cPs). The viscosity of all samples increased slightly during storage (1250-1805 cPs, $p<0.05)$, as well as carbon dioxide content (0.01$1.36 \%, p<0.05)$, except for GTY. The most significant increase in alcohol concentration during storage period was seen in MTY from $0.01 \%$ to $1.36 \%(p<0.05)$. MTY scored significantly higher in most items of the sensory analysis, indicating that the product manufactured by the two-step fermentation method is more acceptable compared with conventionally produced kefirs.
\end{abstract}

Key words: kefir, two-step fermentation, physicochemical property, sensory analysis, Streptococcus thermophilus

\section{Introduction}

Kefir, a cultured milk beverage, originated in the Caucasus Mountains of Russia centuries ago and has been ascribed with many health benefits including antitumor activity (Shiomi et al., 1982), antimicrobial activity (Cevikbas et al., 1994), enhanced immune function (Thoreux and Schmucker 2001), stress relief (Kabayama et al., 1997), specific health benefit (Otle and Cagindi, 2003) and improved digestion (Safonova et al., 1979). This fermented milk product results from the collective action of multiple microorganisms present in kefir grains in milk (Liu et al., 2006).

Kefir has a smooth creamy consistency, somewhat acidic taste mostly due to the presence of lactic acid, mild effervescence due to carbon dioxide, and a low concentration of ethanol produced by yeast cells present in the grains. In addition, a variety of aromatic substances, including acetaldehyde, acetoin, and diacetyl, contribute to its dis-

*Corresponding author: Sung-Sik Yoon, Division of Biological Science and Technology, Yonsei University, Wonju 220-710, Korea. Tel: 82-33-760-2251, Fax: 82-33-760-5576, E-mail: sungsik@yonsei.ac.kr tinctive flavor (Farnworth and Mainville, 2003). Yeasts that are involved in kefir fermentation are critical for its physicochemical and sensory characteristics, and exhibit antibacterial activity against a colonic flora (Farnworth and Mainville, 2003).

However, the kefir manufactured by traditional method produces significant amounts of ethanol and carbon dioxide during the fermentation process, leading to low acceptability among Korean consumers. Therefore, the objective of this study was to develop a flavorful kefir using a two-step fermentation to improve acceptability of this healthful beverage.

\section{Materials and Methods}

\section{Materials}

Market UHT-milk and white sugar powder (Samyang, Korea) were purchased at a local hyper-market. The mixed starter strains (Streptococcus thermophilus, Lactobacillus delbrukii subsp. bulgaricus, L. acidophilus) were manufactured by Lyo-san Inc., Canada, and kefir starter strains (Lactococcus lactis subsp. lactis, Lactococcus lactis subsp. cremoris, Lactococcus lactis subsp. diacetylactis, Leuconostoc mesenteroides subsp. cremoris, Lactobacillus 
kefiri, Kluyveromyces marxianus var. marxianus, Saccharomyces unisporus) were from Body Encology Inc., Canada.

\section{Kefir fermentation methods}

Two-step fermentation (production of MTY): Fifty grams of sugar was added to $1 \mathrm{~L}$ of milk and stirred for 9 $\min$ at $350 \mathrm{rpm}$. The mixture was heated at $85^{\circ} \mathrm{C}$ for 10 $\mathrm{min}$, and then allowed to cool down. For the two-step fermentation, $0.08 \mathrm{~g}$ of starter (Lyo-san) and $1.3 \mathrm{~g}$ of kefir starter (Body Encology) were mixed and added to the cooled mixture. The inoculated solution was incubated in an incubator (JSCI-50T, JRS Inc., Korea) at $37^{\circ} \mathrm{C}$ for $9 \mathrm{~h}$, followed by $15 \mathrm{~h}$ at $22^{\circ} \mathrm{C}$, for a total of $24 \mathrm{~h}$.

Conventional fermentation \#1 (production of GTY): The milk and sugar mixture was prepared as described above, followed by the addition of $0.16 \mathrm{~g}$ of starter (Lyo-san) and incubation at $37^{\circ} \mathrm{C}$ for $24 \mathrm{~h}$.

Conventional fermentation \#2 (production of KEY): The milk and sugar mixture was prepared as described above and an inoculate consisting of 5\% (w/w) kefir grains (Hanheung, Korea) was added. After incubation at $24^{\circ} \mathrm{C}$ for $24 \mathrm{~h}$, the grains were separated from the fermented milk by filtration through a plastic colander and washed prior to the next culture incubation.

The quality of kefirs manufactured in this study was assessed by measuring $\mathrm{pH}$, titratable acidity (TA), LAB count, viscosity, and the amount of alcohol and carbon dioxide $\left(\mathrm{CO}_{2}\right)$ in samples that have completed fermentation and have been stored in refrigerators at $5^{\circ} \mathrm{C}$ for $24 \mathrm{~d}$.

\section{pH and titratable acidity (TA)}

Ten gram samples from each fermentation were taken at $0 \mathrm{~h}, 24 \mathrm{~h}$, and $24 \mathrm{~d}$. Each sample was diluted with 40 $\mathrm{mL}$ of distilled water and stirred on a hot plate (IQ-240, instruments, Inc, USA) for $1 \mathrm{~min}$ at $350 \mathrm{rpm}$. The sample was then filtered through a filter paper (No. 5, Whatman, USA) and $\mathrm{pH}$ of the filtrate was measured using $\mathrm{pH}$ meter (Delta 320, Mettler-Toledo, China). TA was indicated as the content of lactic acid measured until the solution reached a $\mathrm{pH}$ of about 8.1 by adding $0.1 \mathrm{~N} \mathrm{NaOH}$ into $10 \mathrm{~mL}$ of the filtrate.

\section{Microbiological analysis}

For LAB counts, MRS plate count agar (Difco Laboratories, USA) was used. From each fermenting solution, $1 \mathrm{~mL}$ sample was obtained and diluted with $9 \mathrm{~mL}$ of sterile peptone and water diluents. Serial dilutions of each sample were plated in triplicate and incubated at $37^{\circ} \mathrm{C}$ for
$48 \mathrm{~h}$.

\section{Viscosity}

Samples $(100 \mathrm{~mL})$ were placed in a viscometer (LVDV $11+\mathrm{P}$, Brookfield, USA) and the viscosity was measured between 5 to $8 \mathrm{~min}$ with a one minute period at $12 \mathrm{rpm}$.

\section{Alcohol concentration}

To determine alcohol concentration, $100 \mathrm{~mL}$ of samples was obtained from the fermentations every $6 \mathrm{~h}$ to prepare a distillate by steam distillation (Amerine et al., 1967). The concentration of ethanol in the sample was measured using oxidation method (Gupta et al., 1989). After adding $10 \mathrm{~mL}$ of $0.1 \mathrm{~N} \mathrm{KMnO}_{4}$ and $10 \mathrm{~mL}$ of $4 \mathrm{~N} \mathrm{H}_{2} \mathrm{SO}_{4}$ to 10 $\mathrm{mL}$ of each sample distillate, the container was sealed and allowed to stand in a dark place for $24 \mathrm{~h}$. After that, $0.1 \mathrm{~N}$ oxalic acid was titrated against unreacted $\mathrm{KMnO}_{4}$ and the alcohol concentration was calculated using the generated standard curve. The standard curve is shown in Fig. 1.

\section{Carbon dioxide content}

The amount of carbon dioxide was measured using a Carbon Analyzer (Combi Chec9800-1, Ringsted, Denmark) as previously described by Motaghi et al. (1997).

\section{Sensory analysis}

Sensory analysis was performed with the participation of 20 graduate students, who received an explanation of the purpose of the experiment, the evaluation methods used, and the test items. The sensory characteristics consisted of color, flavor, taste, astringency, sweetness, sourness, overall quality, and overall acceptability. The score ranges were from 1 (low or poor) to 7 (high or excellent). The samples were presented in a triplicate cups in random order and coded with three digit random numbers.

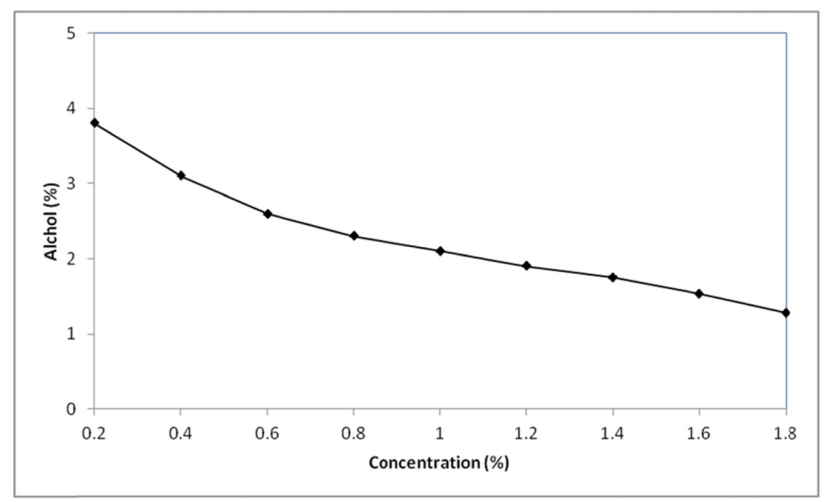

Fig. 1. Standard curve of alcohol concentration. Ethanol concentration was measured by an oxidation method as described in materials and methods. 


\section{Statistical analysis}

Data from the experiments were statistically treated using the Statistic Analysis System (SAS Ver. 9.2 Program, 2008) and verified with Duncan's multiple range test $(p<0.05)$.

\section{Results and Discussion}

\section{Change of $\mathrm{pH}$ and titratable acidity during fermen- tation}

For the purposes of this study, kefir samples were prepared using three different fermentation methods: first, a two-step fermentation producing kefir MTY $\left(1^{\text {st }}\right.$ step: $37^{\circ} \mathrm{C}$ for $9 \mathrm{~h}$; $2^{\text {nd }}$ step: $24^{\circ} \mathrm{C}$ for $15 \mathrm{~h}$ ); second, conventional one step fermentation producing kefir GTY at $37^{\circ} \mathrm{C}$ for $24 \mathrm{~h}$; and third, conventional one step fermentation producing kefir KEY at $22^{\circ} \mathrm{C}$ for $24 \mathrm{~h}$.

The changes in $\mathrm{pH}$ and TA values of the samples from the different preparation methods during fermentation are shown in Fig. 2 and Fig. 3. The $\mathrm{pH}$ and TA differed between the manufacture methods.

$\mathrm{pH}$ of all samples showed same trend, which was a slight decrease during the fermentation $(p<0.05)$. The initial $\mathrm{pH}$ of all samples was between 6.70 and 6.74 and it decreased considerably during fermentation with GTY having the lowest $\mathrm{pH}$ value (3.99) and KEY having the highest value (4.52) observed in the final $\mathrm{pH}$ measurement. Interestingly, the changes in $\mathrm{pH}$ of MTY decreased more dramatically, from 6.72 to 5.30 , during the first fermentation step, whereas the change was more moderate, from 5.30 to 4.03 , in the second step of the fermentation $(p<0.05)$.

The initial TA of all samples was $0.16 \%$ increasing significantly during the fermentation with KEY having the lowest value (0.60) and GTY having the highest value (0.83) observed in the final TA measurement. Again, the TA of MTY increased more rapidly during the first fermentation step, from $0.16 \%$ to $0.42 \%$, and continued rising more slowly during the second fermentation step, from $0.42 \%$ to $0.77 \%(p<0.05)$. This is possibly due to the differences in fermentation temperature at the two steps and the influence of the strains used in the experiment. In the first step of the fermentation, strains of thermophilic $\mathrm{LAB}$ were incubated at $37^{\circ} \mathrm{C}$ causing the values of $\mathrm{pH}$ and TA change dramatically in a shorter period of time, while in the second step fermentation, strains of psychrotrophic $\mathrm{LAB}$ were incubated at $24^{\circ} \mathrm{C}$ causing only moderate changes of $\mathrm{pH}$ and TA.

According to Jung (2007), the production of lactic acid

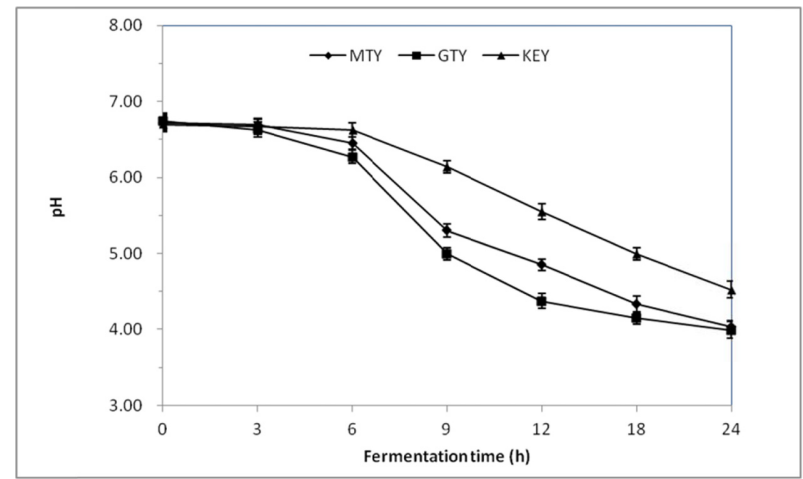

Fig. 2. Change of pH values of samples during fermentation. MTY: Kefir prepared by two step fermentation method ( $1^{\text {st }}$ step: $37^{\circ} \mathrm{C}$ for $9 \mathrm{~h} ; 2^{\text {nd }}$ step: $24^{\circ} \mathrm{C}$ for $\left.15 \mathrm{~h}\right)$, GTY: Yogurt by conventional fermentation method $\left(37^{\circ} \mathrm{C}\right.$ for $24 \mathrm{~h}$ ), KEY: Kefir by conventional fermentation method $\left(22^{\circ} \mathrm{C}\right.$ for $\left.24 \mathrm{~h}\right)$.

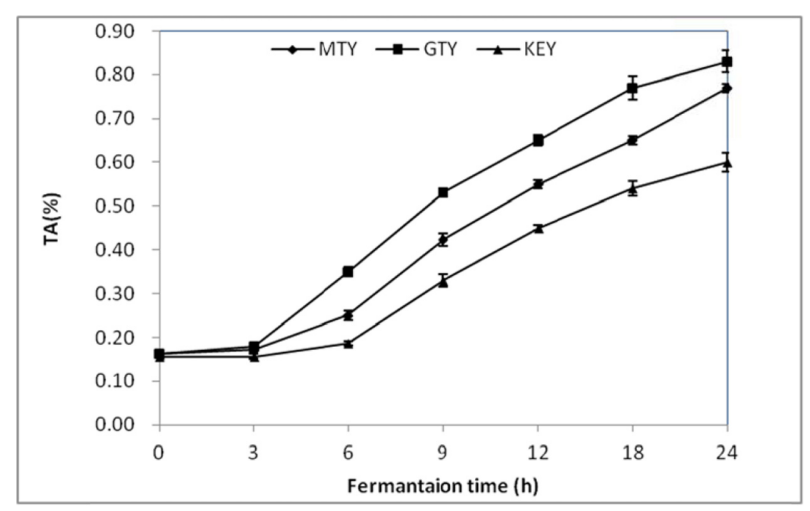

Fig. 3. Change of TA values of samples during fermentation. MTY: Kefir prepared by two step fermentation method $\left(1^{\text {st }}\right.$ step: $37^{\circ} \mathrm{C}$ for $9 \mathrm{~h} ; 2^{\text {nd }}$ step: $24^{\circ} \mathrm{C}$ for $\left.15 \mathrm{~h}\right)$, GTY: Yogurt by conventional fermentation method $\left(37^{\circ} \mathrm{C}\right.$ for $24 \mathrm{~h})$, KEY: Kefir by conventional fermentation method $\left(22^{\circ} \mathrm{C}\right.$ for $\left.24 \mathrm{~h}\right)$.

during the fermentation process gives yogurt its distinctive flavor. When the casein micelles are destabilized, the milk protein coagulates and forms curds giving the yogurt its sour taste (Jung, 2007). In the manufacture of yogurt, low TA was observed at the beginning of fermentation, but the TA increased significantly due to rapid production of acid during the incubation time (Cho, 2005). According to Ozgul and Ali (2010), pH values of kefir samples varied from 4.11 to 4.53 and TA of kefir samples varied from $0.652 \%$ to $1.047 \%$. Collar (1996) found that LAB multiply and produce lactic acid more slowly in mixture with yeasts than in pure culture. This agrees with the finding reported by Irigoyen et al. (2005), who recorded significant differences during kefir manufacture depending on the percentage of kefir grain inoculate added. 


\section{Change of $\mathrm{pH}$ and titratable acidity during storage}

Most kefirs are stored at low temperatures for extended periods of time following fermentation. To investigate the effect of prolonged storage on the quality of kefir products, we measured the $\mathrm{pH}$ and $\mathrm{TA}$ of all samples after storage in the refrigerator at $5^{\circ} \mathrm{C}$ for $24 \mathrm{~d}$. The results of the changes in $\mathrm{pH}$ and TA during the storage period are shown in Fig. 4 and Fig. 5. The initial pH values were between 3.99 and 4.52 and the initial TA values were between $0.6 \%$ and $0.83 \%$ at day 0 . After the storage period of $24 \mathrm{~d}$, the $\mathrm{pH}$ decreased (3.94-4.45) and the TA increased (0.71-0.9\%) significantly $(p<0.05)$.

According to Kang et al. (2013), the $\mathrm{pH}$ decreases due to increasing acidity in the early stage of storage caused by continued metabolic activity of the LAB. The $\mathrm{pH}$ and TA values found in this study are considered to be in the acceptable range of a commercial yogurt. According to Chamber (1979), the appropriate range of $\mathrm{pH}$ for a commercially available yogurt is between 3.27 and 4.53 , and the value of TA is in the range of $0.7 \%$ and $1.20 \%$. Compared with the data reported by Chamber (1979), kefir manufactured by the two-step fermentation method was in the normal ranges of $\mathrm{pH}$ and TA. These results agree with those of Paseephol et al. (2008), who found no significant differences in $\mathrm{pH}$ values (4.2-4.5) and TA (0.8$1.0 \%$ ) among all yogurt samples at $1 \mathrm{~d}$; and after $28 \mathrm{~d}$ of storage at $4^{\circ} \mathrm{C}$, the acidity of all samples increased slightly $(1.0-1.2 \%)$ and $\mathrm{pH}$ dropped marginally (4.1-4.3). This indicated ongoing metabolic and enzymatic activities of mixed cultures during low-temperature storage. The $\mathrm{pH}$ of the kefir did not vary significantly during storage, which is possibly because of the presence of yeast.

\section{Change of $L A B$ counts during fermentation}

The results of LAB counts of all samples during fermentation are shown in Fig. 6. LAB counts in the GTY culture incubated at $37^{\circ} \mathrm{C}$ increased rapidly during the first $12 \mathrm{~h}$ (from 4.29 $\log \mathrm{CFU} / \mathrm{mL}$ to $8.52 \log \mathrm{CFU} / \mathrm{mL}$ ), and then continued to increase slowly up until $18 \mathrm{~h}$ of fermentation (8.79 Log CFU/mL, $p<0.05$ ). After that, the LAB counts in GTY decreased slowly until they reached 8.71 Log CFU/mL, the lowest LAB counts observed in this experiment. On the other hand, LAB counts of MTY in the two-step fermentation increased gradually during the $24 \mathrm{~h}$ of fermentation, reaching $9.28 \mathrm{Log} \mathrm{CFU} / \mathrm{mL}$ in the first step and 9.48 Log CFU/mL in the second step the highest value observed in this experiment.

According to Chung et al. (2007), where the initial starter bacterial counts in yogurt $\left(38^{\circ} \mathrm{C}\right.$ fermentation) were

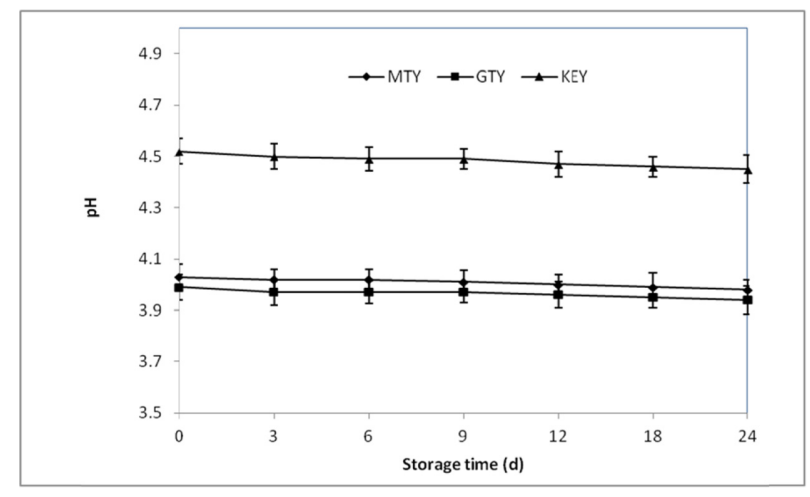

Fig. 4. Change of $\mathrm{pH}$ values of samples during storage at $5^{\circ} \mathrm{C}$. MTY: Kefir prepared by two step fermentation method $\left(1^{\text {st }}\right.$ step: $37^{\circ} \mathrm{C}$ for $9 \mathrm{~h} ; 2^{\text {nd }}$ step: $24^{\circ} \mathrm{C}$ for $\left.15 \mathrm{~h}\right)$, GTY: Yogurt by conventional fermentation method $\left(37^{\circ} \mathrm{C}\right.$ for $24 \mathrm{~h}$ ), KEY: Kefir by conventional fermentation method $\left(22^{\circ} \mathrm{C}\right.$ for $\left.24 \mathrm{~h}\right)$.

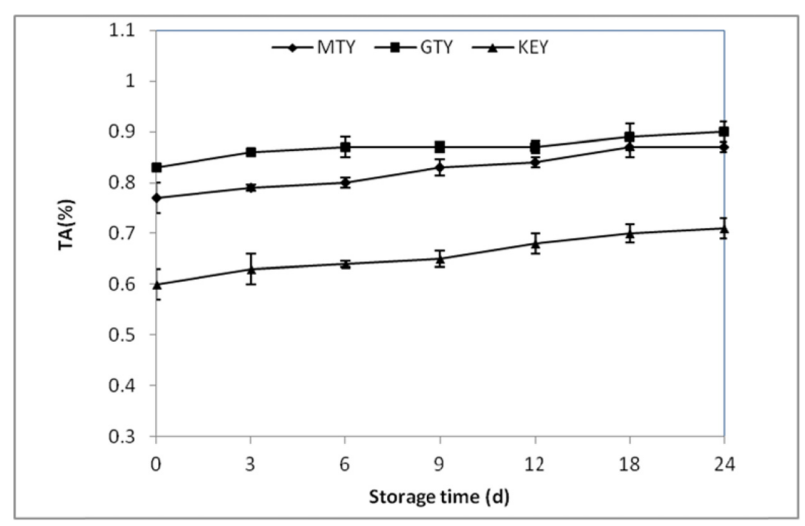

Fig. 5. Change of TA values of samples during storage at $5^{\circ} \mathrm{C}$. MTY: Kefir prepared by two step fermentation method $\left(1^{\text {st }}\right.$ step: $37^{\circ} \mathrm{C}$ for $9 \mathrm{~h}$; $2^{\text {nd }}$ step: $24^{\circ} \mathrm{C}$ for $\left.15 \mathrm{~h}\right)$, GTY: Yogurt by conventional fermentation method $\left(37^{\circ} \mathrm{C}\right.$ for $24 \mathrm{~h}), \mathrm{KEY}$ : Kefir by conventional fermentation method $\left(22^{\circ} \mathrm{C}\right.$ for $\left.24 \mathrm{~h}\right)$.

$1.3 \times 10^{8}$ to $1.7 \times 10^{8} \mathrm{CFU} / \mathrm{mL}$, increasing significantly to $3.48 \times 10^{8}-6.20 \times 10^{8} \mathrm{CFU} / \mathrm{mL}$ at $6 \mathrm{~h}$ of fermentation, which meets the regulatory level of $9.16 \times 10^{8}-1.3 \times 10^{9}$ $\mathrm{CFU} / \mathrm{mL}$ at $24 \mathrm{~h}$. At the $25^{\circ} \mathrm{C}$ fermentation, Leite et al. (2013) reported that the possible starter bacteria counts also increased significantly at $12 \mathrm{~h}$, reaching highest values of $7.8 \mathrm{Log} C F U / \mathrm{mL}$ after $24 \mathrm{~h}$ of fermentation by kefir grain as a starter.

Our result (MTY) is probably explained by the increase of LAB counts, which comprised of the kefir culture, favorably grown at $24^{\circ} \mathrm{C}$ during the second step of fermentation.

\section{Change of $L A B$ counts during storage}

Fig. 7 shows the changes in LAB counts in the kefir 


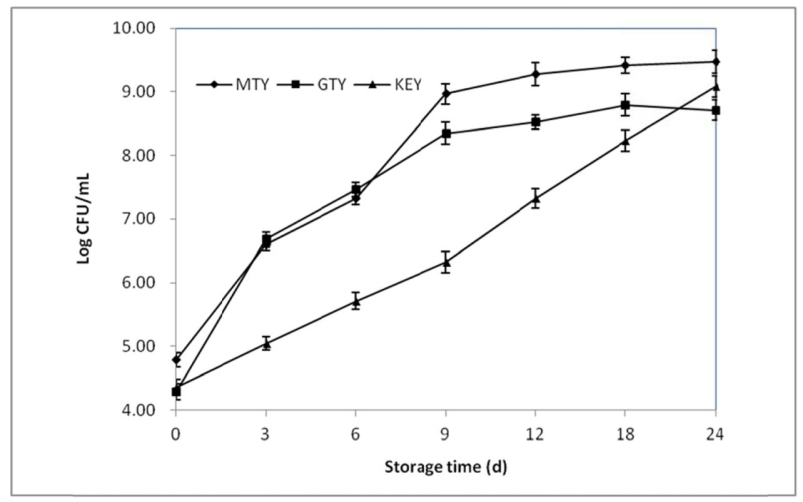

Fig. 6. Change of LAB counts of samples during fermentation. MTY: Kefir prepared by two step fermentation method $\left(1^{\text {st }}\right.$ step: $37^{\circ} \mathrm{C}$ for $9 \mathrm{~h} ; 2^{\text {nd }}$ step: $24^{\circ} \mathrm{C}$ for $\left.15 \mathrm{~h}\right)$, GTY: Yogurt by conventional fermentation method $\left(37^{\circ} \mathrm{C}\right.$ for $24 \mathrm{~h}$ ), KEY: Kefir by conventional fermentation method $\left(22^{\circ} \mathrm{C}\right.$ for $\left.24 \mathrm{~h}\right)$.

samples produced by the different fermentation methods during storage at $5^{\circ} \mathrm{C}$ for $24 \mathrm{~d}$. The LAB counts of all samples were in the range of 8.71-9.48 Log CFU/mL at Day 0 , and increased slightly to $8.79-9.56 \mathrm{Log} \mathrm{CFU} / \mathrm{mL}$ during the storage period $(p<0.05)$.

These results are in confirmation with data reported by Kang (2013), where the number of LAB did not change in the first $9 \mathrm{~d}$ of storage, but increased slightly afterwards. In the study by Leite et al. (2013), microorganisms in kefir were also enumerated during storage at $4^{\circ} \mathrm{C}$ for $28 \mathrm{~d}$. During this period, yeast (approximately $6 \log \mathrm{CFU} / \mathrm{mL}$ ) and LAB counts (approximately $10 \mathrm{Log} \mathrm{CFU} / \mathrm{mL}$ ) remained constant until the end of the storage period, while the count of presumptive AAC (acetic acid bacteria) decreased to $7.2 \mathrm{Log} C F U / \mathrm{mL}$.

According to the current Korean Food and Drug Agency (KFDA, 2007), the shelf life of naturally fermented milk is $10 \mathrm{~d}$ (storage temperature between 0 and $10^{\circ} \mathrm{C}$ ), and the total number of LAB is higher than $1.0 \times 10^{8} \mathrm{CFU} / \mathrm{mL}$ (KFDA, 2007). The number of LAB in all samples in this study increased to higher than the recommended level at $24 \mathrm{~d}$ : in MTY, $3.03 \times 10^{9} \mathrm{CFU} / \mathrm{mL}$; in GTY, $5.16 \times 10^{8} \mathrm{CFU} /$ $\mathrm{mL}$, and in KEY, $1.23 \times 10^{9} \mathrm{CFU} / \mathrm{mL}$. The value was suitable for compositional specifications of fermented milk. In addition, the total number of $\mathrm{LAB}$ in each day for each sample was higher than $1.00 \times 10^{8} \mathrm{CFU} / \mathrm{mL}$ (KFDA, 2007) indicating that the milk has a shelf-life of $24 \mathrm{~d}$.

\section{Change of viscosity during storage}

Fig. 8 shows the changes in viscosity in the kefir samples produced by the different fermentation methods during storage at $5^{\circ} \mathrm{C}$ for $24 \mathrm{~d}$. According to Lee (2008), the

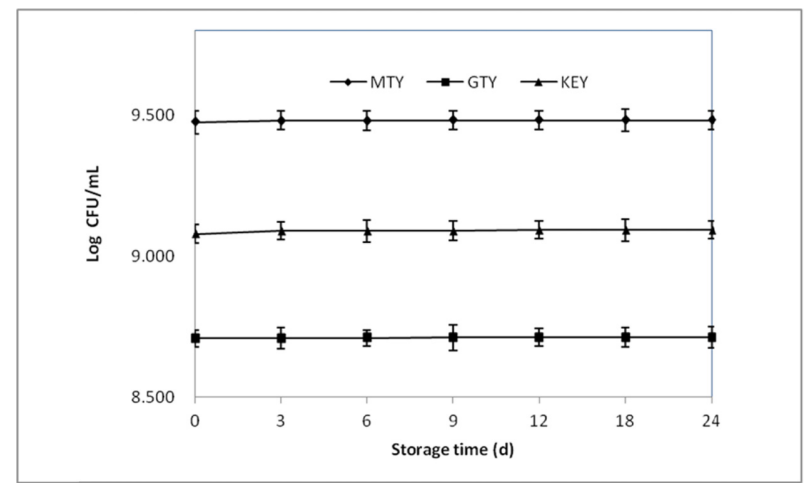

Fig. 7. Change of LAB counts of samples during storage at $5^{\circ} \mathbf{C}$. MTY: Kefir prepared by two step fermentation method $\left(1^{\text {st }}\right.$ step: $37^{\circ} \mathrm{C}$ for $9 \mathrm{~h} ; 2^{\text {nd }}$ step: $24^{\circ} \mathrm{C}$ for $\left.15 \mathrm{~h}\right)$, GTY: Yogurt by conventional fermentation method $\left(37^{\circ} \mathrm{C}\right.$ for $24 \mathrm{~h}), \mathrm{KEY}$ : Kefir by conventional fermentation method $\left(22^{\circ} \mathrm{C}\right.$ for $\left.24 \mathrm{~h}\right)$.

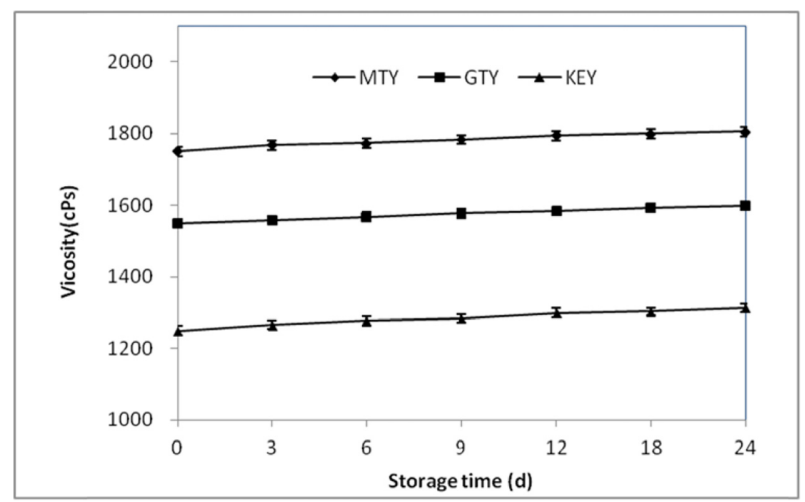

Fig. 8. Change of viscosity of samples during storage at $5^{\circ} \mathrm{C}$. MTY: Kefir prepared by two step fermentation method $\left(1^{\text {st }}\right.$ step: $37^{\circ} \mathrm{C}$ for $9 \mathrm{~h} ; 2^{\text {nd }}$ step: $24^{\circ} \mathrm{C}$ for $\left.15 \mathrm{~h}\right)$, GTY: Yogurt by conventional fermentation method $\left(37^{\circ} \mathrm{C}\right.$ for $24 \mathrm{~h}$ ), KEY: Kefir by conventional fermentation method $\left(22^{\circ} \mathrm{C}\right.$ for $\left.24 \mathrm{~h}\right)$.

palatability of yogurt is influenced by its viscosity. Therefore, the viscosity is an important factor in yogurt. In this experiment, MTY had the highest viscosity (1750-1771 cPs), while KEY had the lowest (1250-1277 cPs) ( $p<$ $0.05)$. The viscosity of all samples tended to increase slightly at the end of the storage period.

This finding agrees with previously reported data for yogurt. Abrahamsen and Holmen (1980) have reported increasing viscosity in yogurt samples during storage. The factors that affect the viscosity of yogurt are the total solids content of the yogurt mixture, the degree of hydrolysis of proteins, the slime-producing capacity and acidproducing capacity of the strain (Tamime and Robinson, 1999). According to Robinson (1981), casein micelles and fat globules most affect the viscosity of milk. Mucoid 
substances made up of sugars that are produced by LAB affect viscosity as well (Rasic and Kurmann 1978). Bae et al. (2000) reported that kefir curds produced by LAB in fermented milk cause high viscosity and the increased viscosity is generally caused by casein.

\section{Change of alcohol concentration during storage}

Changes in alcohol concentration of the samples during storage are shown in Fig. 9. The alcohol concentration of all samples tended to increase slightly during the storage period, except in the case of GTY. KEY samples had the highest alcohol content, starting at $1.3 \%$ and increasing to $1.36 \%$, which is slightly higher than the $1 \%$ observed in a study conducted by Marshall and Cole (1985). Heterofermentative bacteria such as Lactobacillus kefiri and Leuconostoc spp. are also capable of producing ethanol (Magalhaes et al., 2011). GTY had the lowest alcohol content, ranging from $0.03 \%$ to $0.04 \%$ with no significant increase observed during the storage period. MTY had a significant increase in alcohol concentration during the storage period, starting at $0.15 \%$ and increasing to $0.27 \%(p<$ $0.05)$.

According to Farnworth (2005), kefir has a low concentration of ethanol because of the action of yeast cells present in the kefir grains. Acetaldehyde content of yogurt decreases during storage because alcohol dehydrogenase converts acetaldehyde to ethanol (Marshall and Tamime, 1997). Ertekin and Guzel-Seydim (2010) reported that a non-fat kefir sample had the lowest ethanol content (160.24 mg/L) compared with other samples on Day 1; on Day 7, ethanol content ranged between 151.46 and $266.76 \mathrm{mg} / \mathrm{L}$ in all their samples. In another study, etha-

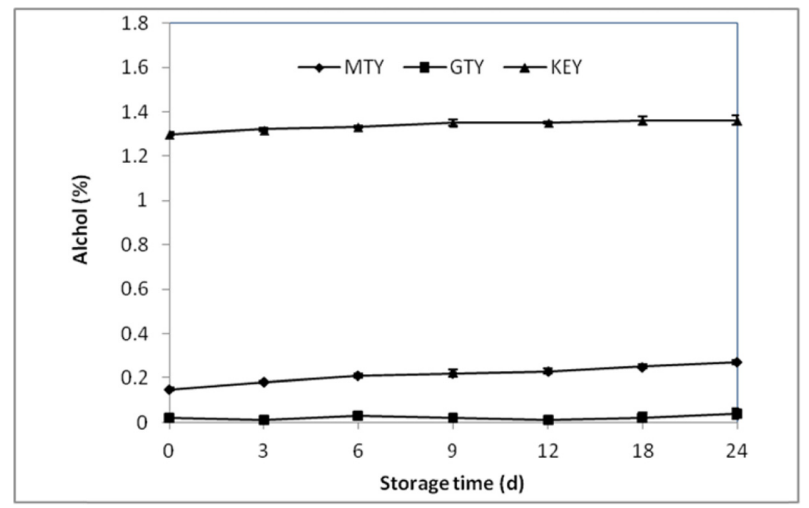

Fig. 9. Change of alcohol concentration of samples during storage at $5^{\circ} \mathbf{C}$. MTY: Kefir prepared by two step fermentation method $\left(1^{\text {st }}\right.$ step: $37^{\circ} \mathrm{C}$ for $9 \mathrm{~h} ; 2^{\text {nd }}$ step: $24^{\circ} \mathrm{C}$ for $15 \mathrm{~h}$ ), GTY: Yogurt by conventional fermentation method $\left(37^{\circ} \mathrm{C}\right.$ for $\left.24 \mathrm{~h}\right)$, KEY: Kefir by conventional fermentation method $\left(22^{\circ} \mathrm{C}\right.$ for $\left.24 \mathrm{~h}\right)$. nol concentrations in two kefir samples made with a starter culture blends and with kefir grains, respectively, were $4,006 \mathrm{mg} / \mathrm{L}$ and $2,998 \mathrm{mg} / \mathrm{L}$ after $24 \mathrm{~h}$ of fermentation; and 4,010 $\mathrm{mg} / \mathrm{L}$ and 3,100 $\mathrm{mg} / \mathrm{L}$ after $7 \mathrm{~d}$ of storage, respectively (Beshkova et al., 2003).

\section{Change of carbon dioxide during storage}

Changes in carbon dioxide content of the kefir during storage are shown in Fig. 10. The carbon dioxide content of all samples tended to increase slightly during the storage period, except for GTY.

KEY samples had the highest carbon dioxide content, starting at $5.92 \%$ and increasing to $6.11 \%$, while GTY samples had the lowest carbon dioxide content, starting at $0.03 \%$ and ending at $0.04 \%(p<0.05)$ with no significant increase observed at the end of the storage period. In the MTY samples, an increase in carbon dioxide content during the storage period was observed, starting at $1.22 \%$ and increasing to $1.53 \%(p<0.05)$.

According to Farnworth (2005), kefir has some effervescence due to a low concentration of carbon dioxide because of the action of yeast present in the kefir grains. According to Lee et al. (2010), kefir was observed as a result of the rapid production carbon dioxide during the fermentation time. The increased carbon dioxide was caused by the yeast that allows kefir products to be commercialized as a sealed product.

\section{Sensory analysis}

Table 1 shows the results of descriptive sensory analysis of the kefir samples produced by the different fermentation methods. Major factors determining the quality of

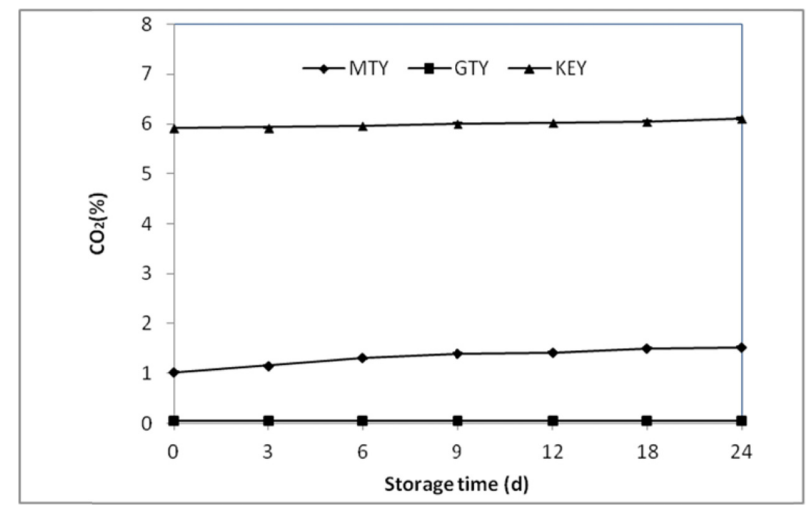

Fig. 10. Change of $\mathrm{CO}_{2}$ contents of samples during storage at $\mathbf{5}^{\circ} \mathbf{C}$. MTY: Kefir prepared by two step fermentation method $\left(1^{\text {st }}\right.$ step: $37^{\circ} \mathrm{C}$ for $9 \mathrm{~h} ; 2^{\text {nd }}$ step: $24^{\circ} \mathrm{C}$ for $\left.15 \mathrm{~h}\right)$, GTY: Yogurt by conventional fermentation method $\left(37^{\circ} \mathrm{C}\right.$ for $24 \mathrm{~h})$, KEY: Kefir by conventional fermentation method $\left(22^{\circ} \mathrm{C}\right.$ for $\left.24 \mathrm{~h}\right)$. 
Table 1. Sensory of all samples

\begin{tabular}{ccccccc}
\hline \hline \multirow{2}{*}{ Sample } & \multicolumn{5}{c}{ Sensory scores } \\
\cline { 2 - 7 } & Color & Flavor & Sweetness & Sourness & Texture & Overall Quality \\
\hline MTY & $5.6 \pm 0.1^{\mathrm{a}}$ & $5.1 \pm 0.3^{\mathrm{ab}}$ & $4.8 \pm 0.2^{\mathrm{a}}$ & $4.8 \pm 0.1^{\mathrm{c}}$ & $4.8 \pm 0.2^{\mathrm{ab}}$ & $6.2 \pm 0.2^{\mathrm{a}}$ \\
GTY & $5.5 \pm 0.1^{\mathrm{b}}$ & $5.2 \pm 0.2^{\mathrm{ab}}$ & $4.2 \pm 0.2^{\mathrm{b}}$ & $5.1 \pm 0.2^{\mathrm{ab}}$ & $4.7 \pm 0.1^{\mathrm{ab}}$ & $5.4 \pm 0.0^{\mathrm{b}}$ \\
KEY & $5.2 \pm 0.1^{\mathrm{c}}$ & $4.6 \pm 0.2^{\mathrm{c}}$ & $4.0 \pm 0.1^{\mathrm{c}}$ & $4.9 \pm 0.1^{\mathrm{ab}}$ & $4.4 \pm 0.0^{\mathrm{c}}$ & $4.4 \pm 0.0^{\mathrm{c}}$ \\
\hline
\end{tabular}

MTY: Kefir prepared by two step fermentation method $\left(1^{\text {st }}\right.$ step: $37^{\circ} \mathrm{C}$ for $9 \mathrm{~h} ; 2^{\text {nd }}$ step: $24^{\circ} \mathrm{C}$ for $\left.15 \mathrm{~h}\right)$.

CTY: Yogurt by conventional fermentation method $\left(37^{\circ} \mathrm{C}\right.$ for $\left.24 \mathrm{~h}\right)$.

KEY: Kefir by conventional fermentation method $\left(22^{\circ} \mathrm{C}\right.$ for $\left.24 \mathrm{~h}\right)$.

${ }^{\mathrm{a} \sim \mathrm{c}}$ Means with the different letter in same column are significantly different by Duncan's multiple range test $(p<0.05)$.

samples are generally appearance, flavor, taste, texture, and overall acceptability. MTY was rated most favorably in sweetness, while KEY was rated lowest in sweetness $(p<0.05)$. The highest score in sourness was assigned to GTY. The highest score in texture was given to MTY, while the lowest score in texture was given to KEY. In this study, KEY samples received the lowest scores in most items of the sensory analysis $(p<0.05)$. In contrast, MTY samples scored significantly higher scores in most items of the sensory analysis compared with the other two types of kefir. In conclusion, kefir manufactured by the two-step fermentation method is highly acceptable in sensory analysis $(p<0.05)$.

According to Bahekar (1975), sensory qualities of kefir made by individual kefir starter culture were judged to be unacceptable. However, their kefir products were not effervescence beverages and lacked the refreshing character of a traditional kefir, such as absence of enough acidity and $\mathrm{CO}_{2}$.

\section{Conclusion}

Results from this study demonstrate that rapid changes in $\mathrm{pH}$ and titratable acidity (TA) were observed in samples from all three manufacturing methods during fermentation process and storage period. The highest LAB counts and viscosity were observed for MTY. The carbon dioxide content of all samples increased slightly during storage, except for GTY. The most significant increase in alcohol concentration during storage period was seen in MTY from $0.01 \%$ to $1.36 \%(p<0.05)$. MTY scored significantly higher in most items of the sensory analysis, indicating that the product manufactured by the two-step fermentation method is more acceptable compared with conventionally produced kefirs.

\section{References}

1. Abrahamsen, R. K. and Holmen, T. B. (1980). Yoghurt from hyperfiltrated, ultrafiltrated and evaporated milk and from milk with added milk powder. Milchwissenschaft 35, 399-402.

2. Amerine, M. A., Berg, H. W., and Cruess, W. W. (1967). The Technology of Wine Making. 2nd ed. AVI Company Inc. p. 696.

3. Bae, J. H., Hong, K. R., Oh, D. H., Park, J. R., and Choi, S. H. (2000) Fermentation characteristic of set-type yoghurt from milk added with mugwort extract. Korean J. Food Sci. 20, 21-29.

4. Bahekar, A. T. (1975) Study on methods for sensory analysis in dairy product. $\mathrm{Ph}$. D. thesis. Kurushetra University, India.

5. Beshkova, D. M., Simova, E. D., Frengova G. I., Simov Z. I., and Dimitrov, Z. P. (2003) Production of volatile aroma compounds by kefir starter cultures. Int. Dairy J. 13, 529-535.

6. Cevikbas, U., Izzettin, F. V., Ayca, B., Uras, F, Uysal, V., Yardimci, T., and Stohs, S. J. (1994) Nephrotoxicit of gentamicin and co-trimoxazole combination in rats. General Pharm. 25, 1185-1189.

7. Chamber, J. V. (1979). Culture and processing techniques important to the manufacture of good quality yogurt. $J$. Cult. Dairy Prod. 14, 28-34.

8. Cho, W. H., (2005) Studies on the blood glucose decreasing yogurt. Masters thesis, Chungnam Univ., Deajon, Korea.

9. Chung, H. J., Choi, M. H., Joo, S. Y., Jung J. Y., and Kim, W. J. (2007) Fermentation properties of yogurt with added nanofitered sunmul powder. Food Qual. Cul. 1, 22-26.

10. Collar, C. (1996) Biochemical and technological assessment of the metabolism of pure and mixed cultures of yeast and lactic acid bacteria in breadmaking applications. J. Biol. Chem. 2, 349-367.

11. Ertekin, B. and Guzel-Seydim, Z. B. (2010) Effect of fat replacers on kefir quality. J. Sci. Food Agric. 90, 543-548.

12. Farnworth, E. R. (2005) Kefir - A complex probiotic. Food Sci. Technol. Bull. 2, 1-17.

13. Farnworth, E. R. and Mainville, I. (2003) Kefir: A fermented milk product. Handbook of Fermented Functional Foods. E. R. Farnworth, ed. CRC Press, London, UK. pp. 77-112.

14. Gupta, K. K. S., Adhikari, M., and Gupta, S. S. (1989) Kinetics of oxidation of ethanol by potassium permanganate in perchloric acid medium. React. Kinet. Catal. Lett. 38, 313-318.

15. Irigoyen, A., Arana, I., Castiella M., Torre, P., and Ibanez, F. C. (2005) Microbiological, physicochemical, and sensory characteristics of kefir during storage. Food Chem. 90, 613-620.

16. Jung, S. W. (2007) Fermentation characteristics of yogurt using lactic acid bacteria with high exopolysaccharide pro- 
duction ability isolated from sourdough. Ph. D. thesis, Dongguk Univ., Seoul, Korea.

17. Kabayama, S., Osada, K., Tachibana, H., Katakura, Y., and Shirahata, S. (1997) Enhancing effects of food components on the production of interferon $\beta$ from animal cells suppressed by stress hormones. Cytotechnol. 23, 119-125.

18. Kang, K. M. Park, C. S., and Lee, S. H. (2013) Effects of Dtagatose on the growth of intestinal microflora and the fermentation of yogurt. J. Korean Soc. Food Sci. Nutr. 42, 348354.

19. Katsiari, M. C., Voutsinas, L. P., and Kondyli, E. (2002) Manufacture of yogurt from stored frozen sheep's milk. Food Chem. 77, 413-420.

20. Korea Food and Drug Agency (2007) Korean Food Standards Codex. pp. 122-123.

21. Lee, J. I., Song, K. Y., Chon, J. W., Hyeon, J. Y., and Seo, K. H. (2010) Physicochemical properties of kefir as dietary supplementary for curing the diabetic mouse. Korean J. Food Nutr. 23, 462-469.

22. Lee, Y. J. (2008) Antioxidant activity in yuza (Citrus junos) and quality characteristics of yuza yogurt. Master thesis Sookmyung Women's Univ., Seoul. Korea.

23. Leite, A. M. O., Leite, D. C. A., Del Aguila, E. M., Alvares, T. S., Peixoto, R. S., Miguel, M. A. L., Silva, J. T., and Paschoalin, V. M. F. (2013) Microbiological and chemical characteristics of Brazilian kefir during fermentation and storage processes. J. Dairy Sci. 96, 4149-4159.

24. Liu, J. R., Wang, S. Y., Lin, Y. Y., Lin, C. W., Chen, M. J., Yueh, P. Y., and Lin. C. W. (2006) The anti-allergenic properties of milk kefir and soymilk kefir and their beneficial effects on the intestinal microflora. J. Sci. Food Agric. 86, 2527-2533.

25. Magalhaes, K. T., Dias, D. R., de Melo Pereira, G. V., Oliveira, J. M., Domingues, L., Teixeira, J. A., de Almeida Silva, J. B., and Schwan., R. F. (2011) Chemical composition and sensory analysis of cheese whey-based beverages using kefir grains as starter culture. Int. J. Food Sci. Technol. 46, 871-878.

26. Marshall V. M., Cole, W. M. (1985) Methods for making Kefir and fermented milks based on Kefir. J. Dairy Res. 52,
451-456.

27. Marshall, V. M. E. and Tamime, A. Y. (1997) Physiology and biochemistry of fermented milks. Microbiology and Biochemistry of Cheese and Fermented Milks. 2nd ed. B. A. Law, ed. Chapman \& Hall, New York, NY. pp. 153-192.

28. Motaghi, M., Mazaheri, M., Moazami, N., Farkhondeh, A., Fooladi, M. H., and Goltapeh, E. M. (1997) Kefir production in Iran. World J. Microbiol. Biotechnol. 13, 579-581.

29. Otle, S. and Cagindi, O. (2003) Kefir: A probiotic dairy-composition nutritional and therapeutic aspects. Pakistan J. Nutr. 2, 54-59.

30. Ozgul, O. and Ali, U. (2010) Biogenic amine content of kefir: A fermented dairy product. Eur. Food Res. Technol. 231, 101107.

31. Paseephol, T., Small, D., and Sherkt, F. (2008) Rheology and texture of set yogurt as affected by inulin addition. J. Texture Stud. 39, 617-634.

32. Rasic, J. L. and Kurmann, J. A., (1978) Yoghurt. Scientific grounds, technology, manufacture and preparations. Technological Dairy Publishing, NY, USA, pp. 110-113

33. Robinson R. K. (1981) Dairy microbiology II. The microbiology of milk products. Applied Science Publishers Ltd. London, UK, pp. 113-156.

34. Safonova, T. I., Iatsyk, G. V., Iurkov, I. A., and Volkova, L. D. (1979) Effect of different types of feeding on the fatty acid makeup of the blood serum in premature infants. Vopr. Pitan 6, 44-49.

35. SAS (2008) ASA/STAT software for PC Release 9.2, Cary, N.C.

36. Shiomi, M., Sasak, I. K., Murofushi, M., and Aibara, K. (1982) Antitumor activity in mice of orally administered polysaccharide from Kefir grain. Jpn. J. Med. Sci. Biol. 35, 75-80.

37. Taminme A. Y. and Robinson R. K. (1999) Yoghurt; science and technology. Woodhead Publishing Ltd and CRC Press LLC. Cambridge, England, pp. 273-286.

38. Thoreux, K. and Schmucker, D. L. (2001) Kefir milk enhances intestinal immunity in young but not old rats. Am. Soc. Nutr. Sci. 131, 807-811.

(Received 2013.9.5/Revised 2013.11.18/Accepted 2013.11.25) 